\title{
Effects of chlorine and pipe material on biofilm development and structure in a reclaimed water distribution system
}

\author{
Haibo Wang, Xuexiang Hu and Chun Hu
}

\begin{abstract}
$\overline{\text { ABSTRACT }}$
The effects of chlorine and pipe material on biofilm development and structure were studied in a model reclaimed water distribution system using annular reactors (ARs). The initial chlorine dose of influents in ARs with polycarbonate pipes and cast iron pipes was 3.59 and $10.15 \mathrm{mg} / \mathrm{L}$, respectively, which could maintain the reclaimed water quality (HPC $10^{2}-10^{3} \mathrm{CFU} / \mathrm{mL}$ ). The chlorine and pipe material influenced the bacterial community. Biofilms formed faster and to a greater extent in ARs with cast iron coupons (HPC $10^{7} \mathrm{CFU} / \mathrm{cm}^{2}$ ) compared to those with polycarbonate coupons (HPC $10^{5}$ $\mathrm{CFU} / \mathrm{cm}^{2}$ ). Using polymerase chain reaction (PCR) and denaturing gradient gel electrophoresis (DGGE) analysis, it was found that Gammaproteobacteria were prevalent in all cases with polycarbonate pipes, whereas with cast iron pipes microbial populations were affiliated with the phylum Proteobacteria, including the classes Alphaproteobacteria, Betaproteobacteria, Gammaproteobacteria and Deltaproteobacteria, followed by the phyla Bacteroidetes and uncultured bacterium.
\end{abstract}

Haibo Wang Xuexiang $\mathrm{Hu}$ Chun Hu (corresponding author) State Key Laboratory of Environmental Aquatic Chemistry,

Research Center for Eco-Environmental Sciences, Chinese Academy of Sciences,

Beijing 10085,

China

E-mail: huchun@rcees.ac.cn

Key words | biofilm, chlorine, PCR-DGGE, reclaimed water distribution system

\section{INTRODUCTION}

Reclaimed water is used as an alternative nonpotable water source for domestic, industrial, agricultural, environmental and recreational purposes. Although much attention to reclaimed water has focused on water quality at the treatment plant, the quality can be degraded by the time it gets to the point of use. Regrowth has been highlighted as the most likely source of organisms detected near the point of use in a water distribution system (WDS). Recent studies have documented that the rapid depletion of disinfectant in reclaimed water increases biodegradable carbon levels and the subsequent regrowth of microorganisms, some of which can be potential opportunistic pathogens (Jjemba et al. 20I0; Weinrich et al. 20I0). Volk \& LeChevallier (I999) indicated that bacterial regrowth could lead to the deterioration of water quality, generation of bad taste and odors, and increase corrosion in WDS. Thus, the detachment of bacteria from biofilm may affect the water quality (Chandy \& Angles 200I).
Bacterial growth on pipe walls depends on various factors, including disinfectant, biodegradable dissolved organic carbon (BDOC) and pipe material (Niquette et al. 2000). The practice of primary disinfection and the maintenance of a disinfectant residual within the WDS are widely used strategies for controlling microbial contaminants and bacterial regrowth (Gagnon et al. 2005). On the other hand, the characteristics of the pipe material greatly influence the biofilm structure in a distribution system. The roughness of the materials used in a WDS has been identified as an important factor affecting bacterial attachment (Percival et al. 1998). Densities of fixed bacterial biomass were measured on different pipe materials, which showed that the densities of bacterial biomass fixed on plasticbased materials were lower than those on cast iron pipes (Niquette et al. 2000).

Different pipe materials, such as cast iron, copper, polyethylene, polycarbonate and so on, were used to study the 
biofilm in a WDS (Lawrence et al. 2000; Lehtola et al. 2004, 2006). In this experiment, an annular reactor (AR) was used to simulate a reclaimed water distribution system (RWDS). Since many cast iron and plastic pipes are used in WDSs in China, polycarbonate and cast iron coupons were selected to investigate microbial communities in an RWDS. Therefore, the major objectives of this work were to (1) examine the effects of different concentrations of chlorine on the development and colonies of effluents and biofilms in a model RWDS, (2) identify bacteria in the bulk fluid and biofilm of different pipes.

\section{MATERIALS AND METHODS}

\section{Model distribution system}

A variety of model systems are available for the cultivation and study of biofilm communities (Codony et al. 2002; Lehtola et al. 2004; Ndiongue et al. 2005). The rotating annular bioreactor is a system that allows the establishment of biofilms under near steady-state conditions. This reactor type has been used to study biofilms (Lawrence et al. 2000; Ndiongue et al. 2005).

Four ARs (Model 1320LJ; BioSurface Technologies Corp., USA) were used to simulate conditions relevant to RWDSs. As shown in Figure 1, the ARs consist of two concentric glass cylinders and a rotating inner drum housing 20 flush-mounted removable coupons, which were either polycarbonate or cast iron. A variable speed motor located above the reactor controls the rotation of the inner drum. The reclaimed water flowed in the region between the

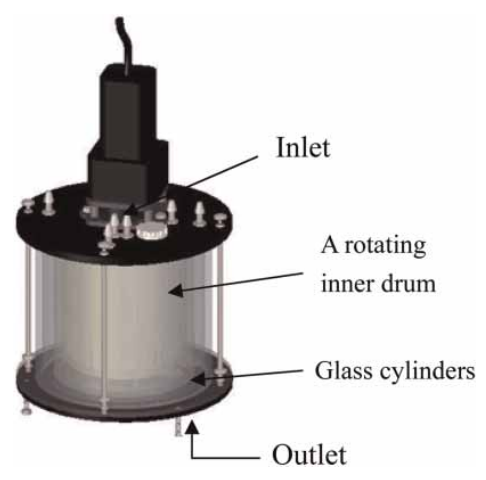

Figure 1 | Scheme of the AR system used in the study. inner drum and the internal glass cylinder with biofilm forming on the coupons. Each coupon had an exposed surface area of $17.5 \mathrm{~cm}^{2}$ for biofilm growth.

There were four ARs in this study, two with polycarbonate coupons and the other two with cast iron coupons. Sodium hypochlorite was added to two ARs, one with polycarbonate coupons and one with cast iron coupons. As a comparison, no disinfectant was added to the other two ARs. Each AR ran for 120 days. The four ARs were set up in parallel and operated at a rotational speed of $50 \mathrm{rpm}$, which corresponded to a shear stress of approximately $0.25 \mathrm{~N} / \mathrm{m}^{2}$.

The hydraulic retention time (HRT) was controlled by the volumetric flow rate of the influents entering the AR. The total working volume in the annular gap was $1 \mathrm{~L}$. Reclaimed water was continuously pumped into the AR by a peristaltic pump at a total flow rate of $2.8 \mathrm{~mL} / \mathrm{min}$, and the HRT for the reactors was $6 \mathrm{~h}$. The external surfaces of the glass cylinders were covered with aluminium foil to prevent phototrophic growth during the experiment.

\section{Water quality and microbial analysis}

The water reclamation plant in the north of China takes in secondary treatment of urban sewage which is then treated by pre-chlorination, flocculation, precipitation, microfiltration and disinfection. Water collected from the water reclamation plant was delivered immediately to the laboratory and subsequently used in the AR. Table 1 shows the general water parameters.

Effluents and biofilm samples were taken from each AR weekly. The heterotrophic plate count (HPC) of these samples were analyzed. First, the biofilm was collected from the coupon according to a described method (Gagnon \& Slawson I999), then HPCs were performed on R2A agar using standard spread-plate techniques (APHA I998). Plates were incubated at $25^{\circ} \mathrm{C}$ for 7 days and then enumerated.

Dissolved organic carbon (DOC) was analyzed using a total organic carbon (TOC) analyzer (Pheonix 8000; Tekmer-Dohrmann, USA). General water analyses were carried out according to the Standard Methods for the Examination of Water and Wastewater (APHA 1998). The morphology of corrosion products was examined using scanning electron microscopy (SEM) (S-3000N; Hitachi, Japan). 


\begin{tabular}{|c|c|}
\hline Parameter & Value \\
\hline $\mathrm{pH}$ & $6.9-8.0$ \\
\hline Turbidity (NTU) & $0.3-0.8$ \\
\hline Conductivity $(\mu \mathrm{S} / \mathrm{cm})$ & $1,176-1,681$ \\
\hline TDS (mg/L) & $580-839$ \\
\hline Alkalinity $\left(\mathrm{mg} \mathrm{CaCO}_{3} / \mathrm{L}\right)$ & $107.8-144.2$ \\
\hline Hardness $\left(\mathrm{mg} \mathrm{CaCO}_{3} / \mathrm{L}\right)$ & $304.7-363.5$ \\
\hline Total iron (mg/L) & $0.027-0.060$ \\
\hline $\mathrm{DO}(\mathrm{mg} / \mathrm{L})$ & $5.5-6.1$ \\
\hline $\mathrm{Cl}^{-}(\mathrm{mg} / \mathrm{L})$ & $162.3-272.8$ \\
\hline $\mathrm{SO}_{4}{ }^{2-}(\mathrm{mg} / \mathrm{L})$ & $143.1-189.0$ \\
\hline $\mathrm{PO}_{4}{ }^{3-}(\mathrm{mg} / \mathrm{L})$ & $0.14-0.30$ \\
\hline DOC (mg/L) & $6.0-7.6$ \\
\hline $\mathrm{HPC}(\mathrm{CFU} / \mathrm{mL})$ & $1,800-2,500$ \\
\hline
\end{tabular}

\section{DNA extraction and PCR-DGGE}

The microbial communities of biofilms on different pipes were characterized using polymerase chain reaction (PCR) and denaturing gradient gel electrophoresis (DGGE) analysis (Martiny et al. 2003; Emtiazi et al. 2004). The procedure including DNA extraction, PCR amplification, DGGE analysis, and sequencing was carried out according to Pozos et al. (2004). FASTA and BLAST DNA homology searches were performed with the NCBI DNA database software of the US National Institutes of Health, accessed on the internet at http://www.ncbi.nlm.nih.gov (Schwartz et al. 2003).

In the step of DNA extraction, for the ARs with polycarbonate pipes, following Farnleitner et al. (2004), $5 \mathrm{~mL}$ of effluents or PBS containing attached microbes was inoculated into the liquid agar for the HPC until the colonies reached $10^{9} \mathrm{CFU} / \mathrm{mL}$. Then, DNA was extracted using an OMEGA Bacterial DNA Kit (D3350-01; OMEGA Bio-tek, USA). For the ARs with cast iron pipes, a chemical method was used for DNA extraction (Araya et al. 2003).

For the PCR-based DGGE analysis, the whole length region of bacteria $16 \mathrm{~S}$ rDNA was amplified with the universal primers 954f(5'-GCACAAGCGGTGGAGCATGTGG-3') and 1369r(5'-GCCCGGGAACGTATTCACCG-3') (Araya et al. 2003). In addition, a GC clamp (5'-CGCCCGCCGCGCCCC GCGCCCGGCCCGCCGCCCCCGCCCC-3') was attached to the $5^{\prime}$-end of the forward primer for subsequent DGGE analysis.

Touchdown PCR was performed as follows: $94^{\circ} \mathrm{C}$ for $10 \mathrm{~min}$, followed by 20 cycles of $94^{\circ} \mathrm{C}$ for $1 \mathrm{~min}, 65^{\circ} \mathrm{C}$ (reduced by $0.5^{\circ} \mathrm{C}$ each cycle) for $1 \mathrm{~min}$, and $72{ }^{\circ} \mathrm{C}$ for $1 \mathrm{~min}, 10$ cycles of $94^{\circ} \mathrm{C}$ for $1 \mathrm{~min}, 55^{\circ} \mathrm{C}$ for $1 \mathrm{~min}$, and $72{ }^{\circ} \mathrm{C}$ for $1 \mathrm{~min}$. Finally, an extension step was carried out at $72{ }^{\circ} \mathrm{C}$ for $8 \mathrm{~min}$.

DGGE analysis was performed using a Bio-Rad D Gene System (Bio-Rad, USA). The PCR products were loaded onto $6 \%(\mathrm{w} / \mathrm{v})$ polyacrylamide gels in $1 \times \mathrm{TAE}(40 \mathrm{mM}$ Tris, $40 \mathrm{mM}$ acetic acid, $1 \mathrm{mM}$ EDTA; pH 7.4) (Grommen et al. 2005). The polyacrylamide gels were made with a denaturing gradient ranging from 40 to $60 \%$. Electrophoresis was performed for $6 \mathrm{~h}$ at $60{ }^{\circ} \mathrm{C}$ and $120 \mathrm{~V}$, and then the gels were stained for 20 min with SYBR Green I (Grommen et al. 2005) nucleic acid gel stain (1:10,000 dilution; FMC BioProducts, USA). Stained gels were photographed immediately on a UV transilluminator with a video camera module.

\section{RESULTS AND DISCUSSION}

\section{Chlorine analysis in ARs with different pipe materials}

In the ARs with polycarbonate coupons, each initial chlorine dose of influents was maintained for 30 days, and the doses were $0.97,1.77,2.38$ and $3.59 \mathrm{mg} / \mathrm{L}$, respectively. Throughout the experiment, the decay of chlorine did not exhibit significant change (Figure 2(a)).

On the other hand, in ARs with cast iron coupons, for the first 5 days, the initial chlorine dose of influents was $1.10 \mathrm{mg} / \mathrm{L}$, and the residual chlorine was $0.20 \mathrm{mg} / \mathrm{L}$. For the next 5 days, initial chlorine dose was $12.63 \mathrm{mg} / \mathrm{L}$; however, the residual chlorine was $0 \mathrm{mg} / \mathrm{L}$. For the next 5 days, the residual chlorine was $1.86 \mathrm{mg} / \mathrm{L}$ when the initial chlorine dose was $28.90 \mathrm{mg} / \mathrm{L}$. Then, the initial chlorine dose was $10.15 \mathrm{mg} / \mathrm{L}$, and the residual chlorine was $1.16 \mathrm{mg} / \mathrm{L}$, which was kept for 105 days (Figure 2(b)).

From the analysis, when residual chlorine was $1.13 \mathrm{mg} / \mathrm{L}$, the initial chlorine dose in the AR with polycarbonate coupons was $2.38 \mathrm{mg} / \mathrm{L}$. However, when residual chlorine was $1.16 \mathrm{mg} / \mathrm{L}$, the initial chlorine dose in the AR with 

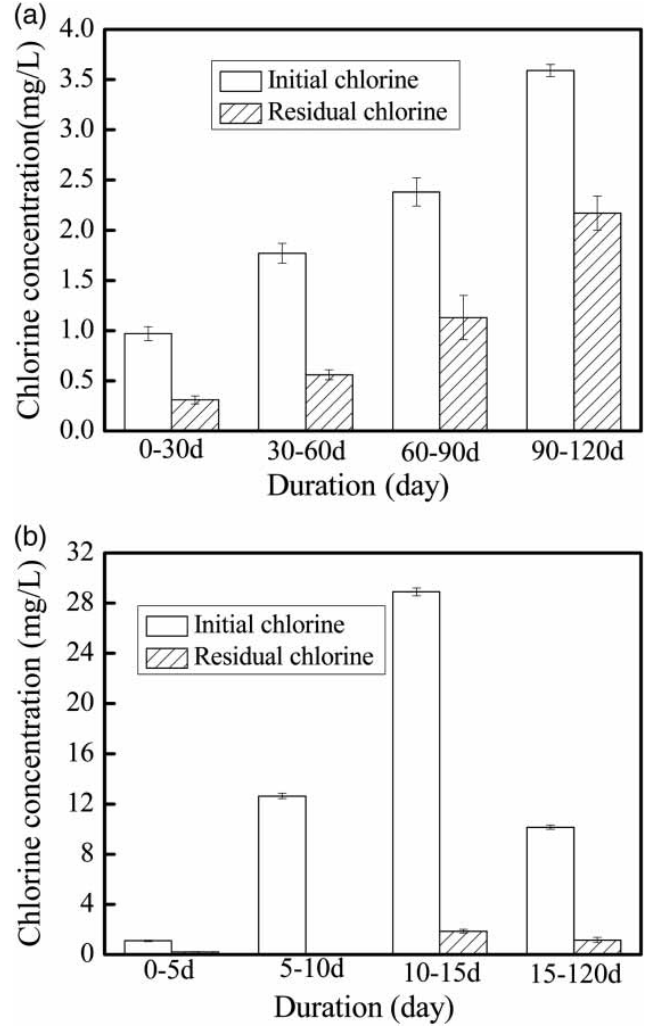

Figure 2 | The change of chlorine concentration in ARs with (a) polycarbonate pipes, (b) cast iron pipes. Error bars represent standard deviations.

cast iron coupons was $10.15 \mathrm{mg} / \mathrm{L}$. Obviously, the chlorine decay in the AR with cast iron coupons was much faster than that in the AR with polycarbonate coupons. The higher chlorine decay rate was attributed to the reaction of chlorine with the cast iron coupons, indicating that corrosion occurred in the cast iron with the addition of sodium hypochlorite. Figure 3 shows the SEM of the corroded cast iron surface for different days. It was obvious that there were corroded particles on the cast iron surface.

\section{Bacterial plate counts in ARs with different pipe materials}

\section{Bacterial plate counts in ARs without chlorine}

The suspended and attached HPC in ARs with polycarbonate and cast iron coupons were analyzed when no chlorine was added to the ARs (Figure 4). In the AR with polycarbonate coupons, the suspended HPC in influents and effluents were almost the same before day 80 , but then the suspended HPC in effluents increased and exceeded that of influents. The attached HPC increased from $3.8 \times 10^{3} \mathrm{CFU} / \mathrm{cm}^{2}$ on day 26 to $1.0 \times 10^{5} \mathrm{CFU} / \mathrm{cm}^{2}$ on day 40 , and then reached steady state (Figure 4(a)). In contrast, in the AR with cast iron coupons, the suspended HPC in influents and effluents were almost the same throughout the operation. The attached HPC was $2.5 \times 10^{7} \mathrm{CFU} / \mathrm{cm}^{2}$ on day 16 , and the steady value was about $1.0 \times 10^{7} \mathrm{CFU} / \mathrm{cm}^{2}$ (Figure $4(\mathrm{~b})$ ). The results indicated that the suspended bacteria attached to the pipes to form biofilm and then reached steady state. However, the quantity of bacteria attached on the cast iron pipes $(1.0 \times$ $10^{7} \mathrm{CFU} / \mathrm{cm}^{2}$ ) was much greater than that on the polycarbonate pipes $\left(1.0 \times 10^{5} \mathrm{CFU} / \mathrm{cm}^{2}\right)$, indicating that bacteria attached to the cast iron coupons more easily than to the polycarbonate coupons.

\section{Bacterial plate counts in ARs with chlorine}

In this experiment, the bacterial plate counts in ARs with chlorine were also analyzed and the chlorine change was consistent with Figure 2.

In the AR with polycarbonate coupons, a decreasing trend was observed for suspended and attached HPCs
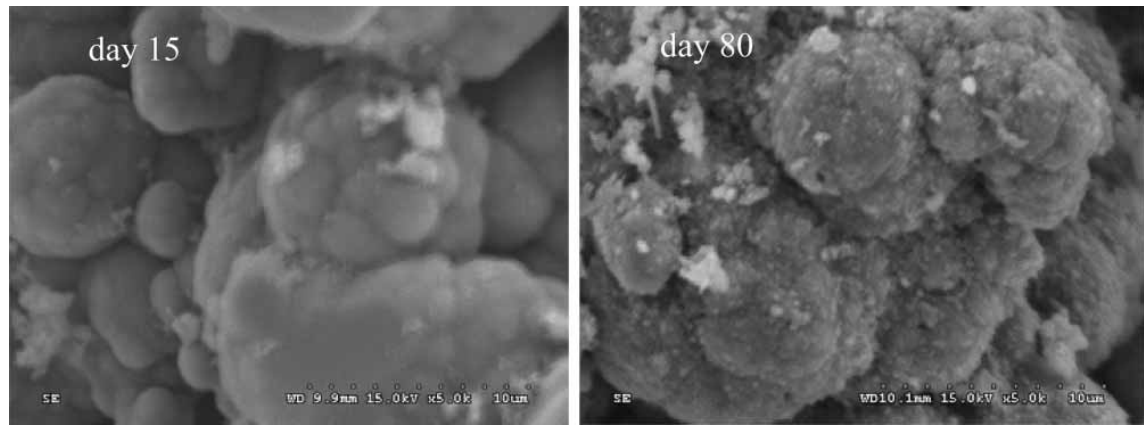

Figure 3 SEM micrographs of corrosion products on cast iron coupons in AR with chlorine for different days. 

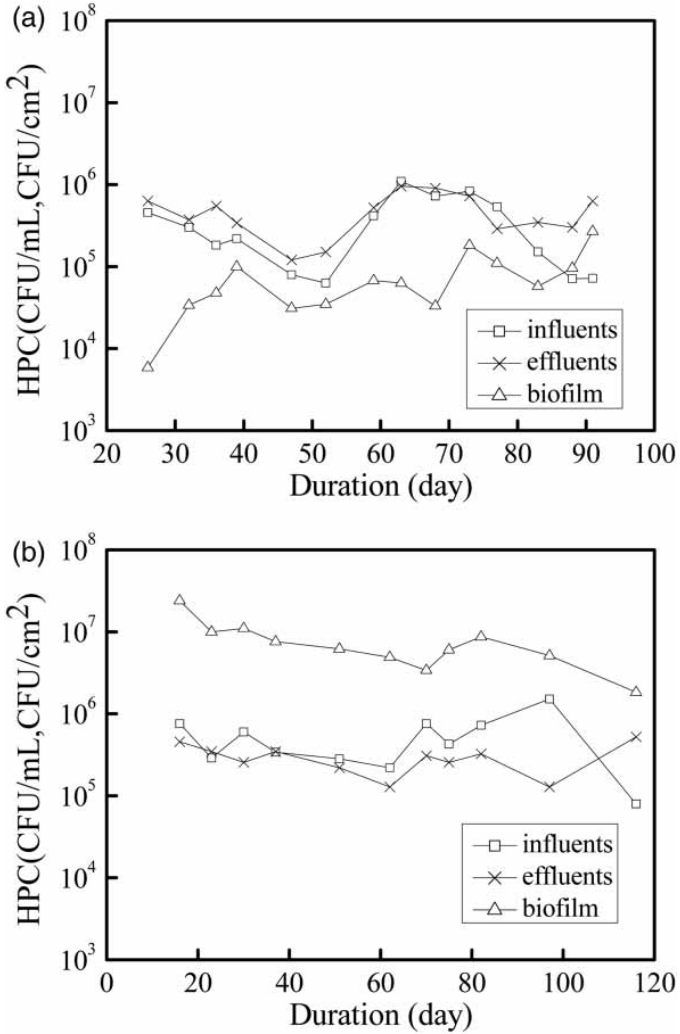

Figure 4 | HPC change of the ARs with (a) polycarbonate pipes, (b) cast iron pipes without chlorine.

with added chlorine (Figure 5(a)). Obviously, the suspended HPC in the effluents was much more than that in the influents until the residual chlorine was $2.17 \mathrm{mg} / \mathrm{L}$. At this time, the HPC in the influents and effluents was the same $\left(4.0 \times 10^{2} \mathrm{CFU} / \mathrm{mL}\right)$, indicating that the microbial quality of water was not affected by the distribution system. And the attached HPC decreased significantly (from $1.3 \times 10^{5} \mathrm{CFU} / \mathrm{mL}$ to $6.3 \times 10^{1} \mathrm{CFU} / \mathrm{mL}$ ) under the same conditions. The results indicated that the chlorine has more significant effect on the biofilm of polycarbonate coupons.

In the AR with cast iron coupons, the suspended and attached HPC also decreased with the addition of chlorine. When the residual chlorine was $0.20 \mathrm{mg} / \mathrm{L}$, the suspended HPC in effluents $\left(7.9 \times 10^{3} \mathrm{CFU} / \mathrm{mL}\right)$ was higher than HPC in influents $\left(3.2 \times 10^{3} \mathrm{CFU} / \mathrm{mL}\right)$. When the residual chlorine was $1.16 \mathrm{mg} / \mathrm{L}$, the suspended HPC decreased from $4.0 \times 10^{5}$ to $3.2 \times 10^{2} \mathrm{CFU} / \mathrm{mL}$, and the attached HPC decreased from $3.2 \times 10^{6}$ to $3.2 \times 10^{5} \mathrm{CFU} / \mathrm{cm}^{2}$ (Figure 5(b)). The results indicated that chlorine has little
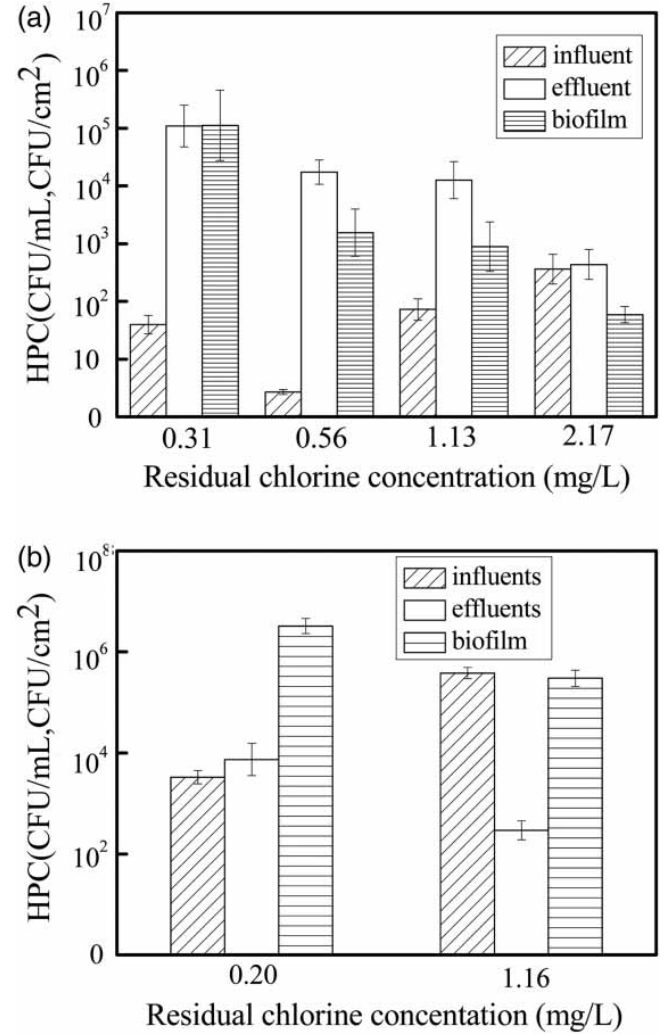

Figure 5 | HPC change of the ARs with (a) polycarbonate pipes, (b) cast iron pipes with chlorine. Error bars represent standard deviations.

effect on the biofilm in AR with cast iron coupons, but it has significant effect on the bacteria in effluents.

The analysis of chlorine decay and bacterial plate counts indicated that the initial chlorine doses of influents in ARs with cast iron coupons and polycarbonate coupons were 10.15 and $3.59 \mathrm{mg} / \mathrm{L}$, respectively, which could maintain the reclaimed water quality (HPC $10^{2}-10^{3} \mathrm{CFU} / \mathrm{mL}$ ) throughout the model distribution system. Obviously, the residual chlorine of the AR with cast iron pipes was $1.16 \mathrm{mg} / \mathrm{L}$ less than that with polycarbonate pipes $(2.17 \mathrm{mg} / \mathrm{L})$ because of the corrosion reaction between chlorine and cast iron.

\section{Bacterial community composition in ARs with different pipe materials}

\section{Bacterial community composition in ARs with polycarbonate pipes}

The bacterial community composition was analyzed by PCR-DGGE. Most of the dominant bands were excised 
Table 2 | Sequencing results of bacteria from the model reclaimed water distribution system with polycarbonate pipes

\begin{tabular}{|c|c|c|c|c|}
\hline Band & Closest relative in GenBank & Similarity (\%) & Bacterial group & GenBank number \\
\hline 1 & Pseudomonas sp. EP-3 & 98 & Gammaproteobacteria & HM031115 \\
\hline 2 & Pseudomonas sp. G1311 & 97 & Gammaproteobacteria & DQ910485 \\
\hline 3 & Uncultured gamma proteobacterium & 99 & Gammaproteobacteria & GU120558 \\
\hline 4 & Pseudomonas sp. IMER-A2-4 & 98 & Gammaproteobacteria & FJ436419 \\
\hline 5 & Uncultured Moraxellaceae bacterium & 99 & Gammaproteobacteria & FJ665906 \\
\hline 6 & Shewanella putrefaciens $C N-32$ & 95 & Gammaproteobacteria & X81623 \\
\hline 7 & Pseudomonas fluorescens & 90 & Gammaproteobacteria & GU198127 \\
\hline 8 & Pseudomonas chlororaphis & 99 & Gammaproteobacteria & FJ652611 \\
\hline 9 & Pseudomonas mediterranea strain & 99 & Gammaproteobacteria & EU647702 \\
\hline 10 & Pseudomonas putida & 96 & Gammaproteobacteria & DQ133506 \\
\hline 11 & Acinetobacter sp. 43 JDE-2009 & 99 & Gammaproteobacteria & FN435916 \\
\hline 12 & Acinetobacter lwoffii & 99 & Gammaproteobacteria & FJ999939 \\
\hline 13 & Pseudomonas lini & 99 & Gammaproteobacteria & GQ844960 \\
\hline 14 & Pseudomonas sp. HUK21 & 99 & Gammaproteobacteria & AB453302 \\
\hline
\end{tabular}

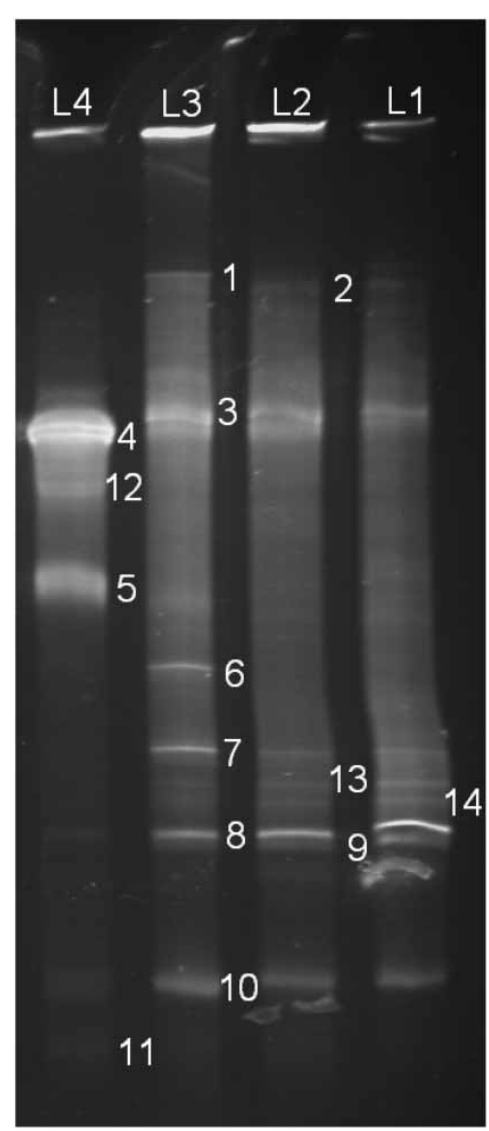

$\begin{array}{llllll}0.50 & 0.60 & 0.70 & 0.80 & 0.90 & 1.00\end{array}$

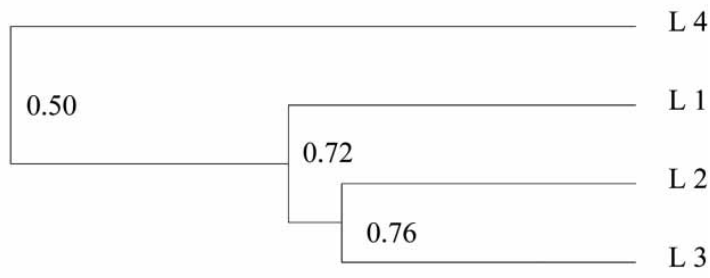

Figure 6 | DGGE and cluster analysis of PCR-amplified 16S-rDNA fragments from reactors with polycarbonate pipes. L1, influents; L2, effluents without chlorine; L3, biofilm without chlorine; L4, biofilm with chlorine. 
from the gels, reamplified, and sequenced successfully. DNA extracts and amplification products were analyzed by electrophoresis in 1\% (w/v) agarose gels. A total of 14 sequences were obtained from ARs with polycarbonate coupons. Proteobacteria were prevalent in all cases, and among them, the gamma subdivision was predominant. Pseudomonas, Shewanella and Acinetobacter were the dominant groups found in most cases (Table 2). These sequences showed high similarity (95-99\%), and they were all affiliated with the phylum Gammaproteobacteria.
The DGGE fingerprints were analyzed using Quantity One software (Bio-Rad, USA). The band-based Dice coefficient $(D c)$ was used to calculate the similarity matrix with a position tolerance of 4\%. For clustering, the unweighted pair group with arithmetic mean (UPGMA) method was applied. Taking into account that the diversity changed because of disinfection treatments, a similarity of about $70 \%$ or more could be interpreted as similar. The colonies of influents, effluents and biofilm were very similar at $D_{\mathrm{C}}=0.76$ and $D_{\mathrm{C}}=0.72$, respectively (Figure 6). This indicated that the

Table 3 | Sequencing results of bacteria from the model reclaimed water distribution system with cast iron pipes

\begin{tabular}{|c|c|c|c|c|}
\hline Band & Closest relative in GenBank & Similarity (\%) & Bacterial group & GenBank number \\
\hline 1 & Uncultured bacterium clone W_0706_38 & 93 & Uncultured bacterium & GQ379388 \\
\hline 2 & Flavobacteria bacterium KF030 gene & 99 & Bacteroidetes & AB269814 \\
\hline 3 & Uncultured Bacteroidetes bacterium clone 1-85 & 100 & Bacteroidetes & HQ224938 \\
\hline 4 & Shewanella putrefaciens strain $\mathrm{ZH} 30$ & 94 & Gammaproteobacteria & HM103350 \\
\hline 5 & Sediminibacterium sp. TEGAF015 gene & 99 & Bacteroidetes & AB470450 \\
\hline 6 & Uncultured bacterium clone MABRDTU30 & 94 & Uncultured bacterium & FJ529983 \\
\hline 7 & Pseudomonas sp. HI-B10 & 97 & Gammaproteobacteria & DQ196474 \\
\hline 8 & Shewanella algae strain UDC323 & 91 & Gammaproteobacteria & GQ245912 \\
\hline 9 & Pseudomonas sp. BWDY-1 & 97 & Gammaproteobacteria & DQ200850 \\
\hline 10 & Shewanella sp. 184 & 94 & Gammaproteobacteria & AF387349 \\
\hline 11 & Rheinheimera taxanensis strain TSWCW2 & 91 & Gammaproteobacteria & GQ284452 \\
\hline 12 & Rheinheimera sp. G2DM-88 & 98 & Gammaproteobacteria & EU037269 \\
\hline 13 & Uncultured bacterium clone nbw627d12c1 & 99 & Uncultured bacterium & GQ112233 \\
\hline 14 & Pseudomonas mendocina strain FB8 & 99 & Gammaproteobacteria & HQ701687 \\
\hline 15 & Propionivibrio sp. Smarlab 3302698 & 96 & Betaproteobacteria & AY643079 \\
\hline 16 & Aeromonas caviae strain T93 & 97 & Gammaproteobacteria & HQ407268 \\
\hline 17 & Aeromonas aquariorum strain MDC47 & 100 & Gammaproteobacteria & EU085557 \\
\hline 18 & Shewanella putrefaciens strain $\mathrm{ZH} 30$ & 96 & Gammaproteobacteria & HM103350 \\
\hline 19 & Sphingomonas sp. BAC84 & 94 & Alphaproteobacteria & EU131006 \\
\hline 20 & Bdellovibrio stolpii & 98 & Deltaproteobacteria & AJ288899 \\
\hline 21 & Methylophilus methylotrophus gene & 99 & Betaproteobacteria & AB193724 \\
\hline 22 & Rheinheimera sp. G2DM-88 & 99 & Gammaproteobacteria & EU037269 \\
\hline 23 & Uncultured bacterium clone ncd1126d03c1 & 100 & Uncultured bacterium & JF094584 \\
\hline 24 & Uncultured Acidovorax sp. clone BPS_CK2 & 100 & Betaproteobacteria & HQ857618 \\
\hline 25 & Rhodocyclus sp. HOD5 & 100 & Betaproteobacteria & AY691423 \\
\hline 26 & Limnobacter thioxidans strain TSWCSN35 & 100 & Betaproteobacteria & GQ284439 \\
\hline 27 & Azospira sp. IHB B2277 & 99 & Betaproteobacteria & HМ233970 \\
\hline 28 & Methylobacterium sp. SuP53 & 96 & Alphaproteobacteria & EU912448 \\
\hline 29 & Thermomonas fusca & 99 & Gammaproteobacteria & AJ519988 \\
\hline 30 & Bosea massiliensis strain JAMSTEC36 & 100 & Alphaproteobacteria & FJ346691 \\
\hline
\end{tabular}


bacteria of biofilm and effluents came from the influents, and the bacteria of influents regrew easily on the biofilm. The bacterial community composition changed markedly when chlorine was added to the reactor $\left(D_{\mathrm{C}}=0.50\right)$ (Figure 6). This could also indicate that the chlorine had a significant effect on the biofilm community composition.

\section{Bacterial community composition in ARs with cast iron pipes}

Sequence analysis of samples obtained from ARs with cast iron coupons indicated that the major populations were affiliated with the phylum Proteobacteria, including the
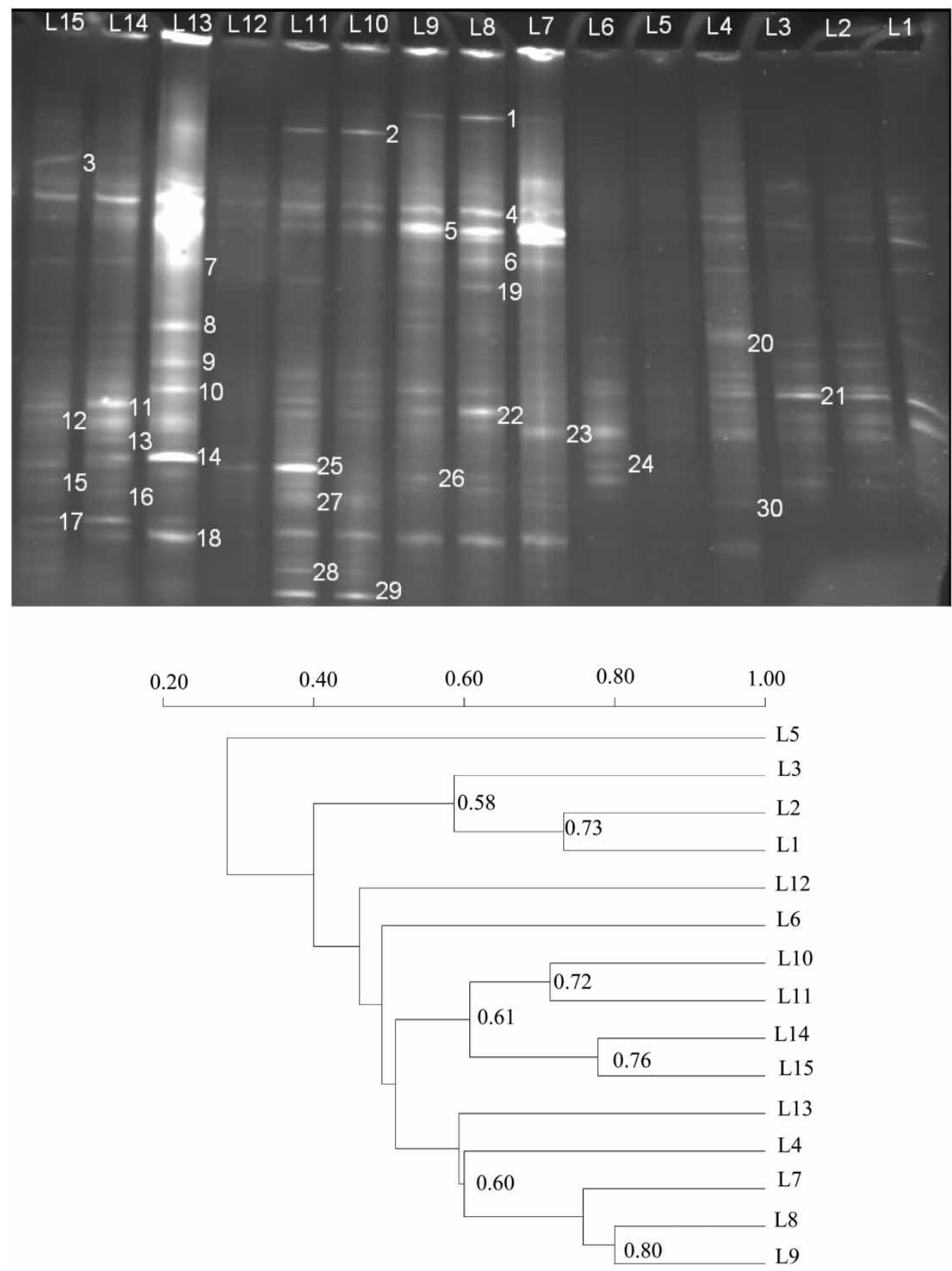

Figure 7 | DGGE and cluster analysis of PCR-amplified 16S-rDNA fragments from reactors with cast iron pipes. Without chlorine: L1, L2, L3, influents of 56 days, 76 days and 140 days; L7, L8, L9, effluents; L13, L14, L15, biofilms. With chlorine: L4, L5, L6, effluents of 56 days, 76 days and 140 days; L10, L11, L12, biofilms. 
classes Alphaproteobacteria, Betaproteobacteria, Gammaproteobacteria and Deltaproteobacteria, followed by the phyla Bacteroidetes and uncultured bacterium (Table 3). The identified bacterial genera included Flavobacteria sp., Acidovorax sp., Sediminibacterium sp., Pseudomonas sp., Shewanella sp., Rheinheimera sp., Propionivibrio sp., Aeromonas sp., Bdellovibrio sp., Methylophilu sp., Sphingomona sp., Rhodocyclus sp., Limnobacter sp., Azospira sp., Thermomonas sp. and Bosea sp. These sequences also showed high similarity (95-99\%) and were affiliated with the phyla Proteobacteria and Bacteroidetes.

From the cluster analysis, microbial populations involving influents from different days (L1, L2, L3) were similar to one another $\left(D_{\mathrm{C}}=0.73\right)$ (Figure 7$)$, indicating that microbial parameters of influents did not change significantly during operation days. Microbial populations involving effluents of different days without chlorine (L7, L8, L9) were also similar to one another $\left(D_{\mathrm{C}}=0.80\right)$ (Figure 7), and they were similar to those involving biofilm (L13). The results indicated that the bacteria in effluents largely came from biofilm, and the bacteria in effluents did not change greatly in ARs without chlorine. Also, the bacterial community on the cast iron pipes did not change greatly during operation days $\left(\mathrm{L} 14, \mathrm{~L} 15, D_{\mathrm{C}}=0.76\right)$. In contrast, when chlorine was added to the ARs, the microbial populations in effluents (L4, L5, L6) and biofilms (L10, L11, L12) of different days changed significantly from the cluster analysis $\left(D_{\mathrm{C}}<0.5\right)$, indicating that the chlorine had an important influence on the microbial community in ARs with cast iron coupons. Furthermore, analysis of the sequences obtained from different coupons indicated that the pipe material had an influence on the bacterial structure.

\section{CONCLUSION}

The initial free chlorine dose of influents in ARs with polycarbonate pipes and cast iron pipes was 3.59 and $10.15 \mathrm{mg} / \mathrm{L}$, respectively, which could maintain the reclaimed water quality (HPC $10^{2}-10^{3} \mathrm{CFU} / \mathrm{mL}$ ). Chlorine has more significant effect on the biofilm of polycarbonate coupons than cast iron coupons. Chlorine and pipe materials influenced the bacterial community. Biofilms formed faster and to a greater extent in ARs with cast iron coupons (HPC $10^{7} \mathrm{CFU} / \mathrm{cm}^{2}$ ) compared to those with polycarbonate pipes (HPC $10^{5} \mathrm{CFU} / \mathrm{cm}^{2}$ ) when no chlorine was added. In ARs with polycarbonate pipes, Gammaproteobacteria were prevalent in all cases, whereas in ARs with cast iron pipes, the microbial populations were affiliated with the phylum Proteobacteria, including the classes Alphaproteobacteria, Betaproteobacteria, Gammaproteobacteria and Deltaproteobacteria, followed by the phyla Bacteroidetes and uncultured bacterium.

\section{$\overline{\text { ACKNOWLEDGEMENTS }}$}

This work was funded by the National Natural Science Foundation of China (No. 50921064, 21125731) and the Federal Department of Chinese Water Control and Treatment (No. 2008ZX07314-003, 2009ZX07424-003).

\section{REFERENCES}

APHA 1998 Standard Methods for the Examination of Water and Wastewater, 20th edition. American Public Health Association, Washington, DC, USA.

Araya, R., Tani, K., Takagi, T., Yamaguchi, N. \& Nasu, M. 2003 Bacterial activity and community composition in stream water and biofilm from an urban river determined by fluorescent in situ hybridization and DGGE analysis. FEMS Microbiol. Ecol. 43 (1), 111-119.

Chandy, J. P. \& Angles, M. L. 20or Determination of nutrients limiting biofilm formation and the subsequent impact on disinfectant decay. Water Res. 35 (11), 2677-2682.

Codony, F., Morato, J., Ribas, F. \& Mas, J. 2002 Effect of chlorine, biodegradable dissolved organic carbon and suspended bacteria on biofilm development in drinking water systems. J. Basic Microbiol. 42 (5), 311-319.

Emtiazi, F., Schwartz, T., Marten, S. M., Sidenstein, P. K. \& Obst, U. 2004 Investigation of natural biofilms formed during the production of drinking water from surface water embankment filtration. Water Res. 38 (5), 1197-1206.

Farnleitner, A. H., Zibuschka, F., Burtscher, M. M., Lindner, G., Reischer, G. \& Mach, R. L. 2004 Eubacterial 16S-rDNA amplicon profiling: a rapid technique for comparison and differentiation of heterotrophic plate count communities from drinking water. Int. J. Food Microbiol. 92 (3), 333-345.

Gagnon, G. A. \& Slawson, R. M. I999 An efficient biofilm removal method for bacterial cells exposed to drinking water. J. Microbiol. Meth. 34 (3), 203-214.

Gagnon, G. A., Rand, J. L., O'Leary, K. C., Rygel, A. C., Chauret, C. \& Andrews, R. C. 2005 Disinfectant efficacy of chlorite and 
chlorine dioxide in drinking water biofilms. Water Res. 39 (9), 1809-1817.

Grommen, R., Dauw, L. \& Verstraete, W. 2005 Elevated salinity selects for a less diverse ammonia-oxidizing population in aquarium biofilters. FEMS Microbiol. Ecol. 52 (1), 1-11.

Jjemba, P. K., Weinrich, L., Cheng, W., Giraldo, E. \& LeChevallier, M. W. 2010 Guidance Document on the Microbiological Quality and Biostability of Reclaimed Water Following Storage and Distribution (WRF-05-002). Water Reuse Foundation, Alexandria, VA.

Lawrence, J. R., Swerhone, G. D. W. \& Neu, T. R. 2000 A simple rotating annular reactor for replicated biofilm studies. J. Microbiol. Meth. 42 (3), 215-224.

Lehtola, M. J., Miettinen, I. T., Keinänen, M. M., Kekki, T. K., Laine, O., Hirvonen, A., Vartiainen, T. \& Martikainen, P. J. 2004 Microbiology, chemistry and biofilm development in a pilot drinking water distribution system with copper and plastic pipes. Water Res. 38 (17), 3769-3779.

Lehtola, M. J., Laxander, M., Miettinen, I. T., Hirvonen, A., Vartiainen, T. \& Martikainen, P. J. 2006 The effects of changing water flow velocity on the formation of biofilms and water quality in pilot distribution system consisting of copper or polyethylene pipes. Water Res. 40 (11), 2151-2160.

Martiny, A. C., Jorgensen, T. M., Albrechtsen, H. J., Arvin, E. \& Molin, S. 2003 Long-term succession of structure and diversity of a biofilm formed in a model drinking water distribution system. Appl. Environ. Microbiol. 69 (11), 6899-6907.

Ndiongue, S., Huck, P. M. \& Slawson, R. M. 2005 Effects of temperature and biodegradable organic matter on control of biofilms by free chlorine in a model drinking water distribution system. Water Res. 39 (6), 953-964.

Niquette, P., Servais, P. \& Savoir, R. 2000 Impacts of pipe materials on densities of fixed bacterial biomass in a drinking water distribution system. Water Res. 34 (6), 1952-1956.

Percival, S. L., Knapp, J. S., Edyvean, R. \& Wales, D. S. 1998 Biofilm development on stainless steel in mains water. Water Res. 32 (1), 243-253.

Pozos, N., Scow, K., Wuertz, S. \& Darby, J. 2004 UV disinfection in a model distribution system: biofilm growth and microbial community. Water Res. 38 (13), 3083-3091.

Schwartz, T., Kohnen, W., Jansen, B. \& Obst, U. 2003 Detection of antibiotic-resistant bacteria and their resistance genes in wastewater, surface water, and drinking water biofilms. FEMS Microbiol. Ecol. 43 (3), 325-335.

Volk, C. J. \& LeChevallier, M. W. 1999 Impacts of the reduction of nutrient levels on bacterial water quality in distribution systems. Appl. Environ. Microbiol. 65 (11), 4957-4966.

Weinrich, L. A., Jjemba, P. K., Giraldo, E. \& LeChevallier, M. W. 20Io Implications of organic carbon in the deterioration of water quality in reclaimed water distribution systems. Water Res. 44 (18), 5367-5375. 